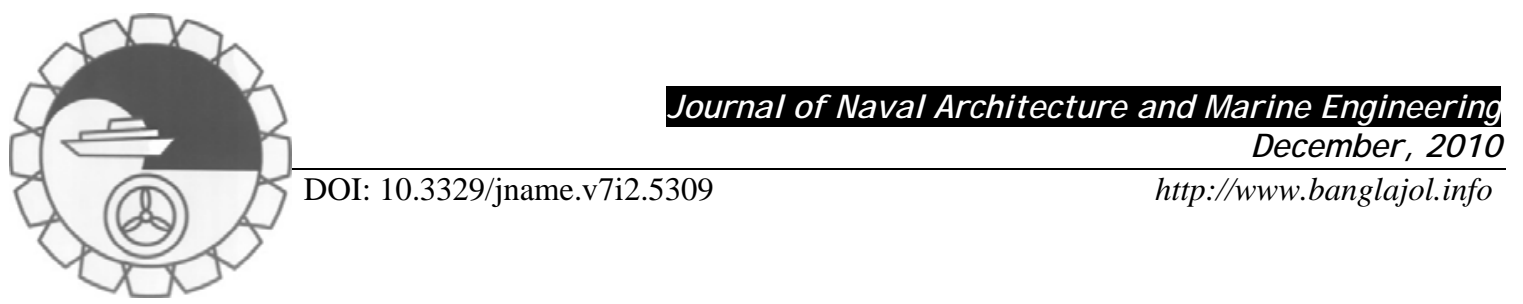

\title{
MECHANICAL PROPERTIESAND CORROSION RESISTANCE OF NORMAL STRENGTH AND HIGH STRENGTH STEELS IN CHLORIDE SOLUTION
}

\author{
Rahbar Ranji A. ${ }^{1}$, Zakeri A.H. ${ }^{2}$
}

\begin{abstract}
${ }^{1}$ Department of Marine Engineering, AmirKabir University of Technology, 15914-Tehran, Iran, Email: rahbar@aut.ac.ir ${ }^{2}$ Department of Marine Engineering, AmirKabir University of Technology, 15914-Tehran, Iran, Email: amirhamed@gmail.com

Abstract:

The corrosion resistance (weight loss) and mechanical properties (i.e. yield strength, ultimate strength and elongation) for three carbon steels, normal strength and high strength steels using tension test are investigated. The specimens are kept in chloride solution (20\% $\mathrm{NaCl})$ up to 240 hours. At every 48 hours, thickness and weight loss are measured and tension test is carried out. It was found that the susceptibility of the steels to corrosion based on their weight loss were identical prior to 144 hours, after that is accelerated for high strength steel. In addition, it was found that manganese (Mn) has reduced corrosion rate at early stage of corrosion. The change in mechanical properties by corrosion for all steels are the same, and ultimate strength is reduced, which for limit state design of aged structure should be taken into account.
\end{abstract}

Keywords: Chloride solution, corrosion rate, carbon steel, tension test.

\section{Introduction}

Corrosion is one of the main reasons of structural failure of aged structures. Different types of corrosion could be happen, e.g. dry corrosion/ wet corrosion, local corrosion/ overall corrosion. Overall corrosion is an attack on the metal when an electrochemical reaction proceeds over entire surface. This type of corrosion which also called uniform corrosion varies from $0.1 \mathrm{~mm} / \mathrm{yrs}$ or higher in marine structures, and has detrimental effects on materials and structures. Many investigations are done on corrosion of steel structures which can be divided into following groups:

\subsection{Estimation of corrosion rate}

In this category, based on statistical data or electrochemical reactions, an equation for corrosion rate, thickness reduction or corrosion resistance is proposed. Among many, some examples in this group are, Melchers (2003), Wang et al. (2003).

\subsection{Determining corrosion effect on mechanical behavior of steel}

In this category, detrimental effects of corrosion on mechanical behavior of steel are studied. In some cases, specimens are kept in solution for some time, and mechanical tests are carried out. For example Khoshnaw et al. (2007) have studied fatigue strength of low alloy steels in chloride solution. Turnbull et al. (2008) have studied stress corrosion cracking of stainless steel in chloride solutions. Chen et al. (2005) have studied mechanical properties of low-alloy steels in atmosphere containing chloride in tension test. In other cases, mechanical tests are done on specimens taken from corroded aged structures. For example Bruneau et al. (1997) and Zuraski et al. (1990) have studied fatigue strength of corroded steel in highway bridges.

\subsection{Determining corrosion effect on structural integrity}

In this category, based on corrosion model, thickness reductions of structural members are predicted. Strength of structures are calculated either numerically (FEM) or by some empirical equations for reduced thickness. For example, Chatterjee et al. (2000) have studied effect of corrosion on a bulk carrier. Wang et al. (2005) have studied buckling and ultimate strength of aged ships.

It is the main objective of this investigation to study the effect of corrosion on mechanical properties of structural steels. For this purpose, some specimens from three different types of structural steels, one normal 
strength steel (St37) and two high strength steel (St52) for simple tension test are prepared. After sustaining in chloride solution for 240 hours, thickness and weight loss are measured at every 48 hours and the specimens are tested in tension

\section{Experimental Method}

\subsection{Test materials}

Two types of carbon steels were studied, i.e. normal strength steel (St37) and high strength steel (St52). The steels were manufactured in different countries and designated by "J", "O" and "Z" (Table 1) where J and O steels are high strength steels, but $\mathrm{Z}$ is normal strength steel. Chemical compositions were analyzed and listed in Table 2.

Table 1: Steel types used in the test

\begin{tabular}{|c|c|c|}
\hline Specimen & Steel & Manufacturer \\
\hline Z & St37-2 & Iran \\
\hline O & St52-3 & Ukraine \\
\hline J & St52-3 & Japan \\
\hline
\end{tabular}

Table 2: Chemical composition of standard and tested steels

\begin{tabular}{|c|c|c|c|c|c|}
\hline \multirow{2}{*}{$\begin{array}{c}\text { Chemical } \\
\text { Compositions }\end{array}$} & \multicolumn{2}{|c|}{ St37-2 } & \multicolumn{3}{c|}{ St52-3 } \\
\cline { 2 - 5 } & Standard & $\mathrm{Z}$ & Standard & $\mathrm{O}$ & $\mathrm{J}$ \\
\hline $\mathrm{C}(\%)$ & $<0.17$ & 0.136 & $<0.2$ & 0.135 & 0.143 \\
\hline $\mathrm{Si}(\%)$ & $<(0.12-0.3)$ & 0.134 & $<0.55$ & 0.284 & 0.280 \\
\hline $\mathrm{Mn}(\%)$ & $0.5<$ & 0.550 & $<1.6$ & 1.37 & 0.32 \\
\hline $\mathrm{P} \%)$ & $<0.04$ & 0.007 & $<0.04$ & 0.023 & 0.018 \\
\hline $\mathrm{S} \%)$ & $<0.035$ & 0.015 & $<0.04$ & 0.011 & 0.009 \\
\hline $\mathrm{Cr}(\%)$ & & 0.016 & & 0.023 & 0.022 \\
\hline $\mathrm{Mo}(\%)$ & & 0.023 & & 0.012 & 0.012 \\
\hline $\mathrm{Ni}(\%)$ & & 0.026 & & 0.010 & 0.010 \\
\hline $\mathrm{Al}(\%)$ & & 0.048 & & 0.034 & 0.034 \\
\hline $\mathrm{Co}(\%)$ & & 0.006 & & 0.005 & 0.005 \\
\hline $\mathrm{Cu}(\%)$ & & 0.04 & & 0.005 & 0.005 \\
\hline $\mathrm{Nb}(\%)$ & & 0.003 & & 0.003 & 0.003 \\
\hline $\mathrm{Ti}(\%)$ & & 0.001 & & 0.013 & 0.010 \\
\hline $\mathrm{V}(\%)$ & & 0.001 & & 0.061 & 0.060 \\
\hline $\mathrm{W}(\%)$ & & 0.008 & & 0.008 & 0.008 \\
\hline $\mathrm{Pb}(\%)$ & & 0.001 & & 0.001 & 0.001 \\
\hline $\mathrm{Sn}(\%)$ & & 0.014 & & 0.001 & 0.001 \\
\hline $\mathrm{As}(\%)$ & & 0.001 & & 0.001 & 0.001 \\
\hline $\mathrm{Ca}(\%)$ & & 0.0001 & & 0.0001 & 0.0001 \\
\hline $\mathrm{B}(\%)$ & & 0.0002 & & 0.0002 & 0.0002 \\
\hline $\mathrm{Zn}(\%)$ & & 0.005 & & 0.005 & 0.005 \\
\hline $\mathrm{Fe}(\%)$ & & 98.96 & & 97.99 & 98.05 \\
\hline
\end{tabular}

As it can be seen from this table, chemical compositions of all steels are within the standard limits. Manganese (Mn) component of normal strength steel is $0.55 \%$ but for high strength steels $\mathrm{O}$ and $\mathrm{J}$ are $1.37 \%$ and $0.32 \%$, respectively. Even though these values are in the accepted range, but high strength steel $\mathrm{J}$ has very low amount of $\mathrm{Mn}$ in comparison to other high strength steel. Silicon (Si) in all steels is within accepted range, in both high strength steels the same and almost two times of normal strength steel. Titanium (Ti) in all steels is very low and in both high strength steels as high as ten times of normal strength steel. Vanadium (V) in al steels is low and in high strength steels as high as high as sixty times of normal strength steel. 
Test materials were cut and machined with specimen thickness $(B) 4 \mathrm{~mm}$, and width $(W) 20 \mathrm{~mm}$. Specimen dimensions are according to standard and capacity of testing machine which are shown in Fig. 1. Distance between gauge points, $L_{0}$ is $50 \mathrm{~mm}$. Surfaces of all specimens first mechanically polished with fine grinding machine and then cleaned thoroughly. Thickness of each specimen is measured at 6 points and then weighed. A solution of 20 percent $\mathrm{NaCl}$ in pure water with volume of $1200 \mathrm{cc}$ used in this investigation. The choice of high chloride concentration was based on the work of other authors, e.g. Speidel (1981) and also to get clear results. All specimens were put simultaneously into separate solutions to avoid galvanic corrosion.

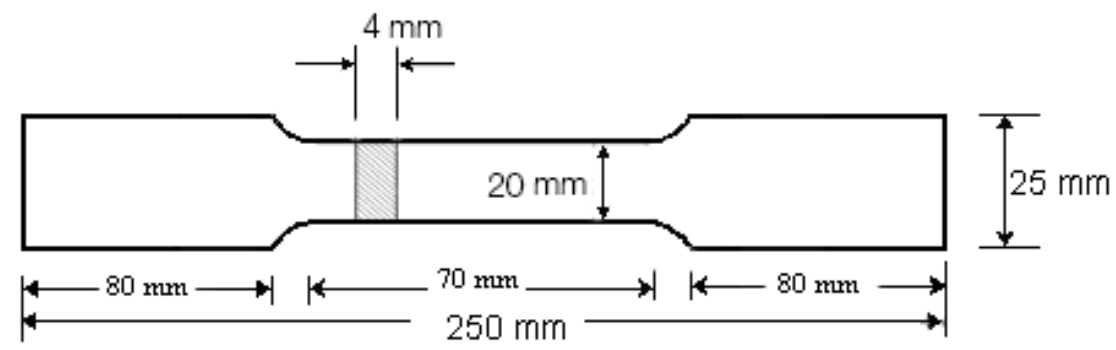

Fig. 1: Schematic drawing of the test specimen

\subsection{Thickness and weight loss}

After every 48 hours all specimens were taken out, cleaned and dried. Average thickness and weight are measured and recorded. One specimen is pulled in tension test machine. Remaining specimens are put into solution. Percentage of $\mathrm{NaCl}$ in all containers at each time are checked and kept constant. Average thickness reduction and weight loss of specimens at different times are depicted in Tables 3 to 5.

Table 3: Weight loss and thickness reduction of steel $\mathrm{Z}$

\begin{tabular}{|c|c|c|c|c|c|c|c|}
\hline \multirow{2}{*}{ Specimen } & & \multirow{2}{*}{ Initial } & \multicolumn{5}{|c|}{ Test time (hour) } \\
\hline & & & $1 \times 48$ & $2 \times 48$ & $3 \times 48$ & $4 \times 48$ & $5 \times 48$ \\
\hline \multirow{2}{*}{$\mathrm{Z} 1$} & Weight (gr) & 181.36 & 157.63 & & & & \\
\hline & Thickness (mm) & 4.10 & 3.65 & & & & \\
\hline \multirow{2}{*}{$\mathrm{Z} 2$} & Weight (gr) & 180.16 & 154.74 & 142.45 & & & \\
\hline & Thickness (mm) & 3.95 & 3.50 & 3.30 & & & \\
\hline \multirow{2}{*}{$\mathrm{Z3}$} & Weight (gr) & 182.63 & 165.34 & 143.60 & 129.15 & & \\
\hline & Thickness (mm) & 4.05 & 3.65 & 3.45 & 3.20 & & \\
\hline \multirow{2}{*}{$\mathrm{Z4}$} & Weight (gr) & 181.08 & 156.42 & 144.56 & 130.26 & 115.06 & \\
\hline & Thickness (mm) & 4.10 & 3.65 & 3.45 & 3.17 & 2.90 & \\
\hline \multirow{2}{*}{ Average reduction } & \multicolumn{2}{|c|}{ Weight (\%) } & 12.56 & 20.82 & 28.67 & 36.46 & \\
\hline & \multicolumn{2}{|c|}{ Thickness (\%) } & 10.81 & 15.71 & 21.90 & 29.27 & \\
\hline
\end{tabular}

\subsection{Mechanical properties}

After every 48 hours, one specimen from each type of steels pulled in a tensile testing machine. The load and elongation were measured continuously and recorded until failure. Stress-strain curves were used to determine the yield stress or proof stress, ultimate stress and elongation (\%). In Tables 6 to 8 results of tests for all specimens are shown. In these tables following parameters are used.

- $\mathrm{R}_{\mathrm{m}}$, Ultimate tensile strength,

- $\quad \mathrm{R}_{\mathrm{eH}}$, Upper yield stress,

- $\mathrm{R}_{\mathrm{eL}}$, Lower yield stress,

- $\mathrm{R}_{\mathrm{P} 0.2}$, Proof stress of 0.2 percent elongation of the initial gauge length,

- $\mathrm{R}_{\mathrm{P} 0.5}$, Proof stress of 0.5 percent elongation of the initial gauge length,

- $\mathrm{R}_{\mathrm{P} 1.0}$, Proof stress of 1.0 percent elongation of the initial gauge length. 
Table 4: Weight loss and thickness reduction of steel O

\begin{tabular}{|c|c|c|c|c|c|c|c|}
\hline \multirow{2}{*}{ Specimen } & & \multirow{2}{*}{ Initial } & \multicolumn{5}{|c|}{ Test time (hour) } \\
\hline & & & $1 \times 48$ & $2 \times 48$ & $3 \times 48$ & $4 \times 48$ & $5 \times 48$ \\
\hline \multirow{2}{*}{ O1 } & Weight (gr) & 223.16 & 211.47 & & & & \\
\hline & Thickness (mm) & 4.16 & 3.90 & & & & \\
\hline \multirow{2}{*}{$\mathrm{O} 2$} & Weight (gr) & 179.21 & 169.04 & 155.53 & & & \\
\hline & Thickness (mm) & 4.00 & 3.95 & 3.80 & & & \\
\hline \multirow{2}{*}{$\mathrm{O} 3$} & Weight (gr) & 183.78 & 175.19 & 150.41 & 127.65 & & \\
\hline & Thickness (mm) & 4.23 & 3.65 & - & 3.36 & & \\
\hline \multirow{2}{*}{$\mathrm{O} 4$} & Weight (gr) & 167.44 & 153.56 & 139.97 & 117.85 & 73.41 & \\
\hline & Thickness (mm) & 3.80 & 3.65 & 3.42 & 3.14 & 2.44 & \\
\hline \multirow{2}{*}{ O5 } & Weight (gr) & 177.86 & 164.57 & 150.70 & 132.32 & - & 54.86 \\
\hline & Thickness (mm) & 4.00 & 3.86 & 3.73 & 3.45 & - & 2.08 \\
\hline \multirow{2}{*}{ Average reduction } & \multicolumn{2}{|c|}{ Weight (\%) } & 6.27 & 15.76 & 28.59 & 56.16 & 69.16 \\
\hline & \multicolumn{2}{|c|}{ Thickness (\%) } & 5.76 & 7.41 & 18.04 & 35.79 & 92.30 \\
\hline
\end{tabular}

Table 5: Weight loss and thickness reduction of steel $\mathrm{J}$

\begin{tabular}{|c|c|c|c|c|c|c|c|}
\hline \multirow{2}{*}{ Specimen } & & \multirow{2}{*}{ Initial } & \multicolumn{5}{|c|}{ Test time (hour) } \\
\hline & & & $1 \times 48$ & $2 \times 48$ & $3 \times 48$ & $4 \times 48$ & $5 \times 48$ \\
\hline \multirow{2}{*}{$\mathrm{J} 1$} & Weight (gr) & 180.54 & 140.73 & & & & \\
\hline & Thickness (mm) & 4.10 & 3.65 & & & & \\
\hline \multirow{2}{*}{$\mathrm{J} 2$} & Weight (gr) & 182.69 & 166.01 & 158.82 & & & \\
\hline & Thickness (mm) & 4.10 & - & - & & & \\
\hline \multirow{2}{*}{ J3 } & Weight (gr) & 178.28 & 162.82 & 154.10 & 134.88 & & \\
\hline & Thickness (mm) & 4.05 & 3.83 & 3.80 & 3.53 & & \\
\hline \multirow{2}{*}{$\mathrm{J} 4$} & Weight (gr) & 168.17 & 151.84 & 143.04 & 121.11 & 76.89 & \\
\hline & Thickness (mm) & 3.75 & 3.60 & 3.40 & 3.16 & 2.42 & \\
\hline \multirow{2}{*}{ J5 } & Weight (gr) & 190.37 & 162.34 & - & 143.82 & - & 62.88 \\
\hline & Thickness (mm) & 4.40 & 3.85 & - & 3.81 & - & 2.25 \\
\hline \multirow{2}{*}{ Average reduction } & \multicolumn{2}{|c|}{ Weight (\%) } & 12.86 & 13.86 & 25.95 & 54.28 & 66.97 \\
\hline & \multicolumn{2}{|c|}{ Thickness (\%) } & 8.23 & 7.75 & 14.08 & 35.47 & 48.86 \\
\hline
\end{tabular}

Table 6: Tension test results of steel Z

\begin{tabular}{|c|c|c|c|c|c|c|c|c|}
\hline Specimen & $\begin{array}{c}\text { Test time } \\
\text { (hour) }\end{array}$ & $\begin{array}{c}\mathrm{R}_{\mathrm{m}} \\
{[\mathrm{MPa}]}\end{array}$ & $\begin{array}{c}\mathrm{R}_{\mathrm{eH}} \\
{[\mathrm{MPa}]}\end{array}$ & $\begin{array}{c}\mathrm{R}_{\mathrm{eL}} \\
{[\mathrm{MPa}]}\end{array}$ & $\begin{array}{c}\mathrm{R}_{\mathrm{p} 0.2} \\
{[\mathrm{MPa}]}\end{array}$ & $\begin{array}{c}\mathrm{R}_{\mathrm{p} 0.5} \\
{[\mathrm{MPa}]}\end{array}$ & $\begin{array}{c}\mathrm{R}_{\mathrm{p} 1.0} \\
{[\mathrm{MPa}]}\end{array}$ & $\begin{array}{c}\mathrm{A} 50 \\
\%\end{array}$ \\
\hline $\mathrm{Z}$ & 0 & 424.9 & - & - & 230.1 & 268.7 & 281.5 & 31.07 \\
\hline $\mathrm{Z1}$ & $1 \times 48$ & 396.2 & - & - & 239.9 & 266.8 & 267.9 & 31.90 \\
\hline $\mathrm{Z} 2$ & $2 \times 48$ & 349.9 & - & - & 231.1 & 232.9 & 239.4 & 31.09 \\
\hline $\mathrm{Z3}$ & $3 \times 48$ & 316.8 & - & - & 214.0 & 221.5 & 233.3 & 28.07 \\
\hline $\mathrm{Z4}$ & $4 \times 48$ & 288.3 & - & - & 192.8 & 192.8 & 194.3 & 26.62 \\
\hline
\end{tabular}

Table 7: Tension test results of steel O

\begin{tabular}{|c|c|c|c|c|c|c|c|c|}
\hline Specimen & $\begin{array}{c}\text { Test time } \\
\text { (hour) }\end{array}$ & $\begin{array}{c}\mathrm{R}_{\mathrm{m}} \\
{[\mathrm{MPa}]}\end{array}$ & $\begin{array}{c}\mathrm{R}_{\mathrm{eH}} \\
{[\mathrm{MPa}]}\end{array}$ & $\begin{array}{c}\mathrm{R}_{\mathrm{eL}} \\
{[\mathrm{MPa}]}\end{array}$ & $\begin{array}{c}\mathrm{R}_{\mathrm{p} 0.2} \\
{[\mathrm{MPa}]}\end{array}$ & $\begin{array}{c}\mathrm{R}_{\mathrm{p} 0.5} \\
{[\mathrm{MPa}]}\end{array}$ & $\begin{array}{c}\mathrm{R}_{\mathrm{p} 1.0} \\
{[\mathrm{MPa}]}\end{array}$ & $\begin{array}{c}\mathrm{A} 50 \\
\%\end{array}$ \\
\hline $\mathrm{O}$ & 0 & 583.5 & - & - & 271.3 & 345 & 423.9 & 19.01 \\
\hline O1 & $1 \times 48$ & 568.3 & - & - & 398.0 & 451.1 & 455.5 & 19.21 \\
\hline O2 & $2 \times 48$ & 503.4 & 408.9 & 404.6 & - & - & - & 20.16 \\
\hline O3 & $3 \times 48$ & 467.5 & - & - & 285.9 & 336.5 & 375.4 & 22.08 \\
\hline O4 & $4 \times 48$ & 352.4 & - & - & 284.3 & 287.4 & 295.7 & 11.56 \\
\hline O5 & $5 \times 48$ & 248.6 & 203.3 & 201.6 & - & - & - & 11.74 \\
\hline
\end{tabular}


Table 8: Tension test results of steel J

\begin{tabular}{|c|c|c|c|c|c|c|c|c|}
\hline Specimen & $\begin{array}{c}\text { Test time } \\
\text { (hour) }\end{array}$ & $\begin{array}{c}\mathrm{R}_{\mathrm{m}} \\
{[\mathrm{MPa}]}\end{array}$ & $\begin{array}{c}\mathrm{R}_{\mathrm{eH}} \\
{[\mathrm{MPa}]}\end{array}$ & $\begin{array}{c}\mathrm{R}_{\mathrm{eL}} \\
{[\mathrm{MPa}]}\end{array}$ & $\begin{array}{c}\mathrm{R}_{\mathrm{p} 0.2} \\
{[\mathrm{MPa}]}\end{array}$ & $\begin{array}{c}\mathrm{R}_{\mathrm{p} 0.5} \\
{[\mathrm{MPa}]}\end{array}$ & $\begin{array}{c}\mathrm{R}_{\mathrm{p} 1.0} \\
{[\mathrm{MPa}]}\end{array}$ & $\begin{array}{c}\mathrm{A} 50 \\
\%\end{array}$ \\
\hline $\mathrm{J}$ & 0 & 576.8 & 470.3 & 462.5 & - & - & - & 21.07 \\
\hline $\mathrm{J} 1$ & $1 \times 48$ & 523.5 & - & - & 356.6 & 406.2 & 419.6 & 22.56 \\
\hline $\mathrm{J} 2$ & $2 \times 48$ & 473.6 & 384.3 & 380.0 & - & - & - & 16.65 \\
\hline J3 & $3 \times 48$ & 418.5 & 386.2 & 382.9 & - & - & - & 14.14 \\
\hline J4 & $4 \times 48$ & 338.5 & 271.7 & 266.9 & - & - & - & 16.07 \\
\hline J5 & $5 \times 48$ & 293.9 & - & - & 230.3 & 233.8 & 237.3 & 12.26 \\
\hline
\end{tabular}

\section{Results and Discussion}

\subsection{Weight loss and thickness reduction}

Relations between thickness reduction, weight loss and test time are shown in Figs. 2 to 4 . As can be seen in all cases, thickness reduction and weight loss have the same tendency, except for high strength steel of type $\mathrm{O}$ in the last stage. Examining the specimen, it can be concluded that in this case, local pitting is proceed and measured points for thickness do not represent true average of thickness reduction.

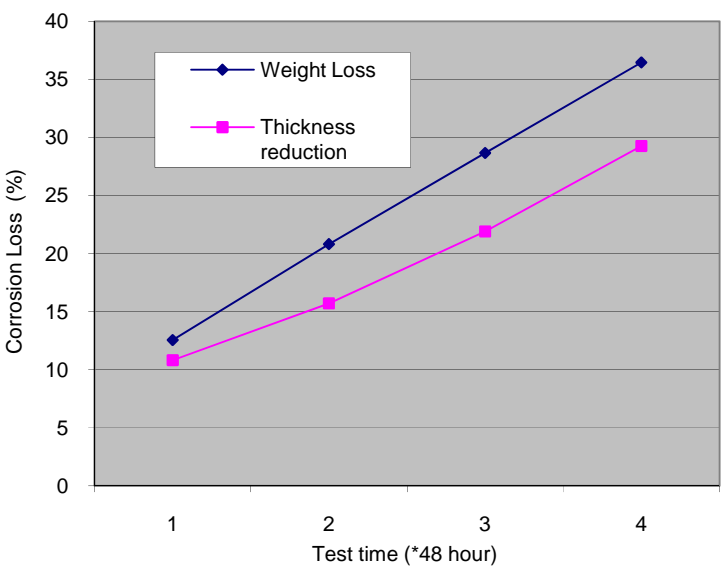

Fig. 2: Corrosion loss of steel Z

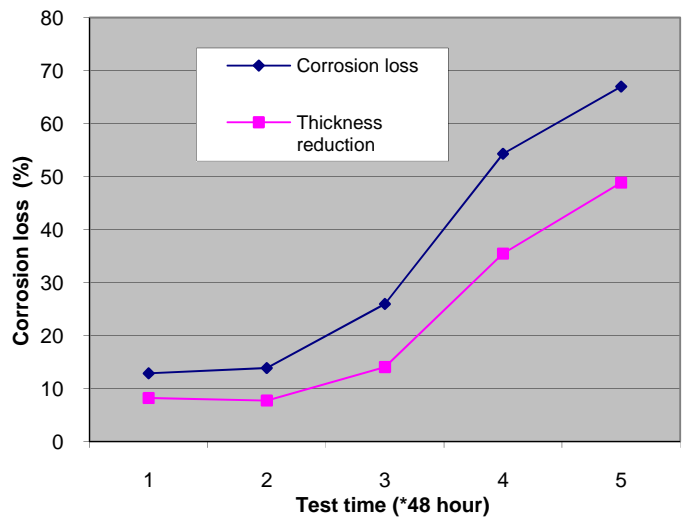

Fig. 4: Corrosion loss of steel J

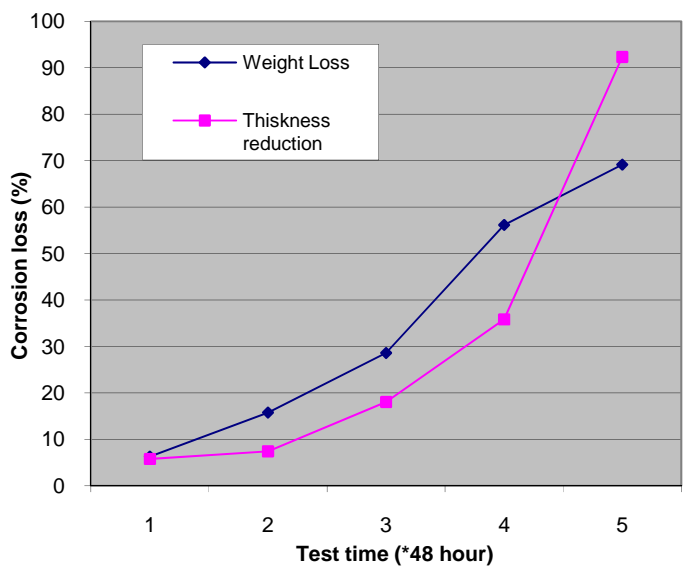

Fig. 3: Corrosion loss of steel O

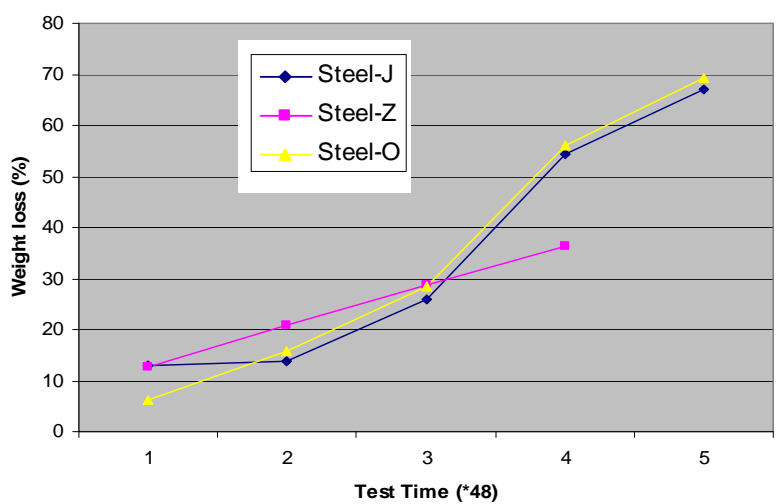

Fig. 5: Weight loss of steels as a function of test time 
In Fig. 5, relation between weight loss and test time for all steels is shown. As can be seen, the corrosion rates are almost identical prior to 144 hours in solution, regardless of steel type or chemical compositions. After that, the corrosion rate is accelerated for high strength steels. Comparing two high strength steels of $\mathrm{J}$ and $\mathrm{O}$, it can be concluded that corrosion resistance of high strength steel containing higher manganese (Mn), is higher at early stage of corrosion.

\subsection{Effects of corrosion on mechanical properties}

Figs. 6 and 7 show ultimate stress (UTS) and elongation decrease with an increase in test time, respectively. The decrease in UTS is identical for all steels prior to 144 hours, after that accelerated for high strength steels. On the other hand, the change of elongation is less regular, but decreases in general.

From Tables 6 to 8, it can be concluded that generally yield stress decreases by corrosion, but there are some discrepancy in results. This is due to pitting and stress concentrations which cause local yielding. Local yielding forges ahead yielding strength and this is the reason of discrepancy of yield stress. In Table 9 weight loss, thickness reduction, yield stress and ultimate stress of all steels after 192 hours in solution are compared. It is apparent that the mechanical properties were reduced by corrosion, but yield stress reduction is higher for steels $\mathrm{Z}$ and $\mathrm{J}$ in comparison with other mechanical properties reductions.

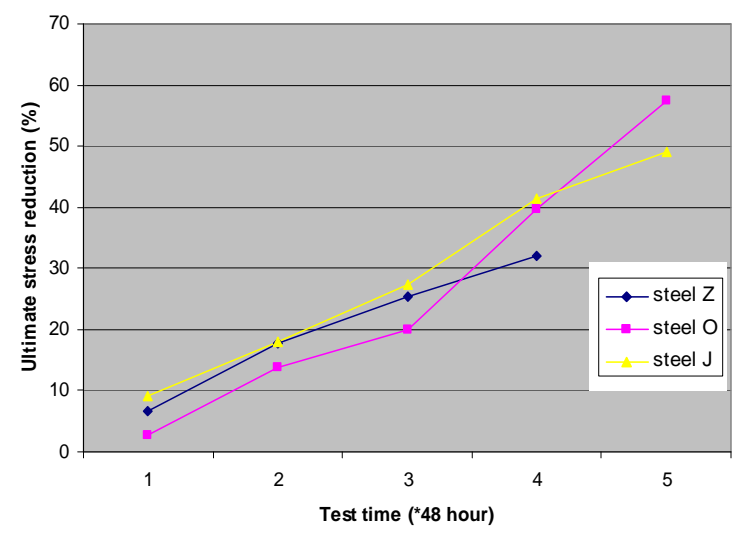

Fig. 6: Ultimate stress (UTS) reduction as a function of test time

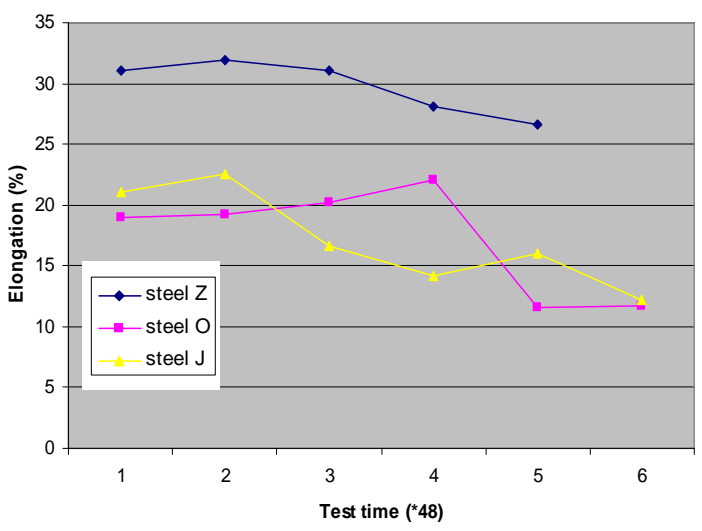

Fig. 7: Elongation (\%) of steels as a function of test time

Table 9: Comparison of mechanical strength, weight loss and remaining cross section of all steels after 192 hours in solution

\begin{tabular}{|c|c|c|c|}
\hline Steel & Steel Z & Steel J & Steel O \\
\hline Weight loss (\%) & 36.46 & 56.16 & 54.28 \\
\hline Thickness reduction (\%) & 29.27 & 35.79 & 35.47 \\
\hline Remaining cross section ratio & 0.92 & 0.632 & 0.739 \\
\hline Yield stress ratio & 0.838 & 0.833 & 0.578 \\
\hline Ultimate stress ratio & 0.679 & 0.603 & 0.587 \\
\hline Elongation ratio & 0.857 & 0.608 & 0.763 \\
\hline
\end{tabular}

\section{Conclusions}

Both normal strength and high strength carbon steels were tested in chloride solution and subjected to tension. The results indicate that the corrosion rate of steels based on their weight loss was identical prior to 144 hours, after that it is accelerated for high strength steels. In addition, it was found that manganese (Mn) has reduced corrosion rate at early stage of corrosion. The change in mechanical properties by corrosion for all steels are the same and ultimate strength is reduced, which for limit state design of aged structure should be taken into account. 


\section{References}

Bruneau M., Zahrai S.M. (1997): Effect of severe corrosion on cyclic ductility of steel, J. of Struc. Eng., Vol. 123, No. 11, pp. 1478-1486

Chatterjee P.C., Das P.K. (2000): Builk carrier safety and the effects of corrosion, Int. Shipbuild. Progr., Vol. 47, No. 449, pp. 37-52

Chen Y.Y., Tzeng H.J., Wei L.I., Shih H.C. (2005): Mechanical properties and corrosion resistance of low-alloy steels in atmospheric conditions containing chloride, Materials Science \& Engineering A, 398, pp. 47-59. doi:10.1016/j.msea.2005.02.064

Khoshnaw F.M., Kheder A.I., Ali F.S.M. (2007): Corrosion behavior of nitrided low alloy steel in chloride solution, Anti-Corrosion Methods and Materials, 54/3, pp. 173-179. doi: 10.1108/000355907107486441

Melchers R.E. (2003): Probabilistic models for corrosion in structural reliability assessment-part 1: Empirical models, Trans. of ASME, Vol. 125, pp. 264-271

Melchers R.E. (2003): Probabilistic models for corrosion in structural reliability assessment-part 2: Models based on mechanics, Trans. of ASME, Vol. 125, pp. 272-288

Speidel M.O., (1981) Stress corrosion cracking of stainless steels in NaCl solution, Metall. and Mat. Trans. A, Vol. 12, No. 5, pp.779

Turnball A., Zhou S. (2008): Impact of temperature excursion on stress corrosion cracking of stainless steels in chloride solution, Corrosion Science, Vol. 50, pp. 913-917. doi:10.1016/j.corsci.2008.01.020

Wang Ge, Spencer J., Elsayed T. (2003): Estimation of corrosion rates of structural members in oil tankers, 22th Int. Conf. on offshore Mech. and Arctic Eng., Cancun, Mexico, 8-13 June

Wang Ge, Spencer J., Sun H. (2005): Assessment of corrosion risks to aging ships using an experience database, J. of Offshore Mech. And Arctic Eng., Vol. 127, pp. 167-174

Zuraski P.D., Johnson J.E. (1990), Fatigue strength of deteriorated steel highway bridge, J. of Struc. Eng., Vol. 116, No. 10, pp. 2671-2690 